alloy has a yield strength near 1,950 MPa, and a tensile strength near 2,200 MPa, with total elongation of $8.2 \%$ and a uniform elongation of $3.8 \%$. The combination of strength and ductility is competitive with the best reported for both maraging and secondary hardening steels (Fig. 1).

Finally, the results presented by $\mathrm{Lu}$ and colleagues document that $\mathrm{Ni}(\mathrm{Fe}, \mathrm{Al})$ can be a very effective hardening precipitate, leading to UHSSs that are also economically attractive since they avoid expensive species such as Co and Ti. But there are a number of other issues that must be addressed before these alloys become viable candidates for important structural applications. An important example is the fracture toughness of the alloy, which is not reported. There is reason for concern, since alloys strengthened by $\mathrm{NiAl}$ precipitates, such as $\mathrm{PH} 13-8$, are susceptible to cleavage fracture at ambient temperature ${ }^{12}$ and lose toughness rapidly with strength ${ }^{7}$. However, brittle cleavage fracture is not overcome metallurgically by changing the precipitate distribution, but rather by modifying the underlying martensitic microstructure, as is done effectively, for example, in the AerMet 100 alloy ${ }^{13}$. A similar approach could be useful in the 18-3 alloy discussed here.

\section{J. W. Morris Jr is in the Department of Materials Science and Engineering, University of California, Berkeley, California 94720, USA. e-mail:jwmorris@berkeley.edu}

References

1. Jiang, S. et al. Nature 544, 460-464 (2017).

2. Kinney, C. C, Pytlewski, K. R., Khachaturyan, A. G. \& Morris, J. W. Jr Acta Mater. 69, 372-385 (2014).

3. Galindo-Nava, E. I., Rainforth, W. N., Rivera-Díaz-del-Castillo, P. E. J. Acta Mater. 117, 270-285 (2016).

4. Handerhan, K. J., Garrison, W. M. \& Moody, N. R. Met. Trans. A 20, 105-123 (1989)

5. Novotny, P. M. \& Maurer, G. E. Adv. Mater. Process. $165,37-40$ (2007).

6. Hickey, C. F. Jr, Dix, D. W. \& Kagan, D. Mechanical Property Characterization of Vascomax T-300 (US Army Materials Technology Laboratory, 1989).

Wert, D. E. \& DiSabella, R. P. Adv. Mater. Process. 164, 34-36 (2006).

8. Glazer, J. \& Morris, J. W. Jr Acta Metall. 36, 907-915 (1988).

9. Ayer, R. \& Machmeier, P. M. Metall. Trans. A 24, 1943-1955 (1993).

10. Hu, Z. \& Wu, X. Micron 34, 19-23 (2003).

11. Vasudevan, V. K., Kim, S. J. \& Wayman, C. M. Metall. Trans. A 21, 2655-2668 (1990).

12. Leitner, H., Schober, M., Schnitzer, R. \& Zinner, S. Mat. Sci. Eng. A 528, 5264-5270 (2011).

13. Sato, K. Improving the Toughness of Ultrahigh Strength Steel $\mathrm{PhD}$ thesis, Univ. California, Berkeley (2002).

\title{
SEEKING COMFORT IN THE IRON AGE
}

The sophistication of Viking material culture, such as the fine quality of their decorative metalwork, has long given the lie to the old idea that they were barbaric brutes - a reputation that attests to the trauma left in Europe by the Viking raids of the ninth to the eleventh centuries. There have even been suggestions that Vikings used advanced navigation techniques based on the ability of certain local minerals - such as calcite or Iceland spar - to influence polarized light ${ }^{1,2}$, although there is no archaeological evidence to support the idea.

But a new discovery must surely sink the image of unreconstructed brutishness once and for all: Vikings preferred soft underwear. They made their underclothing not from coarse hemp, which the Vikings used for sailcloth and wall hangings ${ }^{3}$, but from finer flax.

Along with wool and nettle, hemp and flax were the only choices available for textile manufacture in Scandinavia in the late Iron Age of the sixth to the eleventh centuries. Cotton could theoretically have been acquired from late Roman culture, but there is no evidence of it. Wool, needless to say, would be rather itchy for clothing worn against the skin, but the other options all seem viable in principle.

Lukešová and colleagues ${ }^{4}$ have investigated the fibres in ten textile items - nearly all of them from the tenth century - collected from excavations of Viking graves in various Norwegian provinces and kept at the University Museum of Bergen. All are made from plant fibres and, with the exception of a purse, all are items of clothing. One appears to be a man's shirt, while the others are women's clothing, mostly shifts worn as underwear. The sex of the wearer could be identified from other items in the respective graves, which indicate also that the bodies were high-ranking members of Viking society.

Plant fibres can be distinguished by polarized-light microscopy. The fibres contain bundles of cellulose chains called fibrils, which wind helically around the cell walls in either a lefthanded (S) or right-handed (Z) twist (the same terminology is used for the twisting of macroscopic strands in textile threads). Flax and nettle have an S twist, hemp a Z twist, and these different fibre orientations show up as differences in the colour of the light transmitted through crossed-polar filters under the microscope: a socalled modified Herzog test. Nettle and flax can usually be differentiated, meanwhile, by the telltale presence of calcium oxalate crystals in the former.

With the exception of one ambiguous sample, all of those studied were made of flax. It is easier to make softer fabrics from this plant, since on average its fibres are finer - to

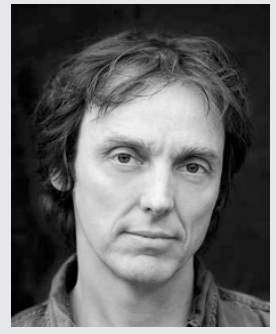

PHILIP BALL

achieve the same qualities with hemp, one would need to sort the fibres to remove the coarser strands. The same is true of nettle, which has the added drawback that it can't be cultivated as a textile crop but must be collected from the wild.

As ever with such archaeological studies, the findings shouldn't be generalized too readily. And it remains unclear whether the fibre choice was aesthetic or simply dictated by local availability. All the same, when it comes to underwear, given the choice we would probably have the same preference as the Viking noblewomen.

References

1. Ropars, G., Gorre, G., Le Floch, A., Enoch, J. \& Lakshminarayanan, V. Proc. R. Soc. A 468, 671-684 (2011).

2. Ropars, G., Lakshminarayanan, V. \& Le Floch, A Contemp. Phys. 55, 302-317 (2014).

3. Skoglund, G., Nockert, M. \& Holst, B. Sci. Rep. 3, 2686 (2013).

4. Lukešová, H., Palau, A. S. \& Holst, B. J. Archaeol. Sci. Rep. 13, 281-285 (2017). 